\title{
DESKRIPSI PENGARUH PARAMETER TERHADAP KESTABILAN PERILAKU SISTEM BANDUL GANDA SEDERHANA
}

\author{
Thoufina Kurniyati \\ Mahasiswa Jurusan Matematika Fakultas Sains dan Teknologi UIN Maulana Malik Ibrahim Malang \\ E-mail: thoufinakurniyati@yahoo.co.id
}

\begin{abstract}
ABSTRAK
Sistem bandul ganda sederhana merupakan pengembangan sistem bandul sederhana. Penurunan model bandul ganda sederhana berasal dari persamaan Euler-Lagrange. Sistem bandul ganda sederhana didapatkan dengan asumsi besar sudut perpindahan benda pertama maupun benda kedua sangat kecil.

Penelitian terdahulu [1] membahas mengenai kestabilan dan solusi eksak dari sistem bandul ganda sederhana, selanjutnya pada penelitian ini difokuskan untuk mendeskripsikan kestabilan perilaku pada sistem dengan parameter yang berbeda. Hasil penelitian ini menunjukkan sistem memiliki titik tetap trivial, nilai eigen imajiner murni yang berarti sistem berayun di sekitar titik tetap, dan solusi sistem berupa solusi periodik untuk perubahan besar sudut benda pertama dan kedua $\left(\theta_{1}, \theta_{2}\right)$ serta solusi quasiperiodic untuk laju kecepatan benda satu dan benda dua $\left(\ddot{\theta}_{1}, \ddot{\theta}_{2}\right)$. Perubahan parameter tidak mempengaruhi kestabilan sistem bandul ganda sederhana.
\end{abstract}

Kata Kunci: sistem bandul ganda sederhana, analisis perilaku, titik tetap, nilai eigen, vektor eigen, solusi periodik, solusi quasiperiodic

\section{ABSTRACT}

Simple double pendulum system is the development of a simple pendulum system. The decline in the simple model of a double pendulum is derived from the Euler-Lagrange equation. Simple double pendulum system obtained by assuming a large angle displacement of the object first and second objects is very small.

Previous research by [1] discuss the stability and the exact solution of a simple double pendulum system, further research is focused to describe the stability of the behavior of the system with different parameters. The results of this study indicate the system has a nontrivial fixed point, purely imaginary eigenvalues which means the system swinging around a fixed point, and system solutions in the form of periodic solutions for a major change angle first and second objects $\left(\theta_{1}, \theta_{2}\right)$ and quasi-periodic solutions to the rate of velocity one and two object $\left(\ddot{\theta}_{1}, \ddot{\theta}_{2}\right)$. Parameter changes do not affect the stability of a simple double pendulum system

Keywords : simple double pendulum system, behavioral analysis, fixed point, eigen value, eigen vector, periodic solutions, quasiperiodic solutions

\section{PENDAHULUAN}

Peranan teori dan peranan penerapan matematika tidak dapat dipisahkan. Banyak konsep abstrak matematika yang dikembangkan karena kebutuhan untuk menjawab permasalahan dari dunia nyata dan bidang ilmu lain [2].

Pemodelan matematika dapat diterapkan ke berbagai disiplin ilmu lain, salah satunya adalah sistem bandul ganda sederhana. Sistem bandul ganda sederhana merupakan pengembangan bandul sederhana, pengertian bandul sederhana yaitu benda ideal yang terdiri dari sebuah titik massa, yang digantungkan pada tali ringan yang tidak dapat mulur [3].
Penelitian sebelumnya [1] membahas mengenai solusi eksak dan kestabilan sistem bandul ganda sederhana, selanjutnya pada penelitian ini difokuskan mendeskripsikan kestabilan perilaku dengan parameter yang berbeda, parameter tersebut adalah massa benda pertama $m_{1}$.

Salah satu permasalahan yang menggunakan sistem bandul ganda adalah pada sistem kerja tim SAR (Search and Rescue) dan suplai makanan atau amunisi ke barak analisis dengan menggunakan helikopter. Berbagai bencana alam yang ada di Indonesia akhir-akhir ini, menyebabkan kerja Tim SAR semakin tinggi. Keefektifan kerja Tim SAR sangat diperlukan 
agar bantuan makanan dan, pakaian ataupun obat-obatan dapat tersebar merata.

Sesuai dengan latar belakang yang dikemukakan untuk melanjutkan penelitian sebelumnya, maka dalam penelitian ini penulis mengambil tema “Deskripsi Pengaruh Parameter terhadap Kestabilan Perilaku Sistem Bandul Ganda Sederhana".

\section{TINJAUAN PUSTAKA}

\section{Bandul Ganda Sederhana}

Sistem bandul ganda sederhana adalah sistem yang terdiri dari dua benda $B_{1}$ dan $B_{2}$ dengan massa masing-masing benda adalah $m_{1}$ dan $m_{2}$. Selain itu benda tersebut masingmasing dihubungkan dengan dua helai kawat yang kuat tapi ringan $L_{1}$ dan $L_{2}$ dengan panjang masing-masing kawat adalah $l_{1}$ dan $l_{2}$, benda $B_{1}$ terpasang pada ujung kawat $L_{1}$ (ujung kawat $L_{1}$ lainnya terpasang mantap pada sebuah bidang). Sementara itu benda $B_{2}$ terpasang pada ujung kawat $L_{2}$ di bawah pengaruh grafitasi (ujung kawat $L_{2}$ lainnya mantap terpasang pada benda pertama $B_{1}$ ). Sistem bandul ganda memiliki 4 (empat) parameter yakni $l_{1}, l_{2}, m_{1}$ dan $m_{2}$ dengan dipengaruhi oleh grafitasi, bandul ganda berosilasi pada bidang vertikal dengan sudut perpindahan untuk suatu waktu adalah $\theta_{1}(t)$ dan $\theta_{2}(t)$ [1]. Sistem bandul sederhana adalah sebagai berikut

$\left\{\begin{array}{c}\left(m_{1}+m_{2}\right) l_{1}^{2} \ddot{\theta}_{1}+m_{2} l_{1} l_{2} \ddot{\theta}_{2}+\left(m_{1}+m_{2}\right) l_{1} g \theta_{1}=0 \\ m_{2} l_{1} l_{2} \ddot{\theta}_{1}+m_{2} l_{2}{ }^{2} \ddot{\theta}_{2}+m_{2} l_{2} g \theta_{2}=0\end{array}\right.$

Variabel dan parameter yang digunakan adalah

$m_{1} \quad$ : Massa benda pertama dalam satuan slug

$m_{2}$ : Massa benda kedua dalam satuan slug

$l_{1} \quad$ : Panjang kawat/tali pertama dalam satuan kaki

$l_{2} \quad$ : Panjang kawat/tali kedua dalam satuan kaki

$g \quad: \quad$ Gravitasi bumi dalam satuan kaki/s ${ }^{2}$

$\theta_{1}(t)$ : Sudut perpindahan benda pertama pada waktu $t$ dalam satuan radian

$\theta_{2}(t)$ : Sudut perpindahan benda kedua pada waktu $t$ dalam satuan radian

$\ddot{\theta}_{1}(t)$ : Laju kecepatan benda pertama terhadap waktu dalam satuan kaki/s ${ }^{2}$

$\ddot{\theta}_{2}(t)$ : Laju kecepatan benda kedua terhadap waktu dalam satuan kaki/s ${ }^{2}$

\section{Analisis Model Bandul Ganda Sederhana}

Pada bagian ini akan dianalisis model bandul ganda sederhana yang dibangun ke dalam bentuk sistem persamaan diferensial. Analisis dimulai dengan penurunan dari persamaan Euler-Lagrange.

Dalam mekanika Lagrangian, evolusi sistem dijelaskan dalam hal koordinat umum dan kecepatan umum. Dalam kasus ini, sudut defleksi bandul $\theta_{1}, \theta_{2}$ dan kecepatan angular dapat diambil sebagai variabel umum. Dengan menggunakan variabel-variabel tersebut, dibangun persamaan Lagrangian untuk bandul ganda kemudian persamaan diferensial EulerLagrange.

Koordinat bandul pertama didefinisikan

$$
\begin{gathered}
x_{1}=l_{1} \sin \theta_{1}, \\
y_{1}=-l_{1} \cos \theta_{1} .
\end{gathered}
$$

Energi kinetik $(T)$ secara umum dinyatakan

$$
T=\frac{1}{2} m v^{2} .
$$

Energi kinetik benda pertama $\left(T_{1}\right)$ dinyatakan

$$
T_{1}=\frac{m_{1}}{2}\left(l_{1}^{2} \dot{\theta}_{1}^{2}\right),
$$

dan energi kinetik benda kedua $\left(T_{2}\right)$ dinyatakan

$$
\begin{aligned}
T_{2}=\frac{m_{2}}{2}\left[l_{1}{ }^{2} \dot{\theta}_{1}{ }^{2}\right. & +l_{2}{ }^{2} \dot{\theta}_{2}{ }^{2} \\
& +2 l_{1} l_{2} \dot{\theta}_{1} \dot{\theta}_{2} \cos \left(\theta_{1}\right. \\
& \left.\left.-\theta_{2}\right)\right] .
\end{aligned}
$$

Energi potensial $(V)$ secara umum dinyatakan

$$
V=m g h \text {. }
$$

Energi potensial benda pertama $\left(V_{1}\right)$ dinyatakan

$$
V_{1}=-m_{1} g l_{1} \cos \theta_{1},
$$

dan energi potensial benda kedua dinyatakan

$$
V_{2}=-m_{2} g\left(l_{1} \cos \theta_{1}+l_{2} \cos \theta_{2}\right) \text {. }
$$

Persamaan Lagrangian adalah selisih antara energi kinetik dengan energi potensial.

$$
L=T-V=T_{1}+T_{2}-\left(V_{1}+V_{2}\right)
$$

Substitusi (1)-(4) ke persamaan (5) maka didapatkan

$$
\begin{aligned}
L=\left(\frac{m_{1}}{2}+\frac{m_{2}}{2}\right) & l_{1}{ }^{2} \dot{\theta}_{1}{ }^{2}+\frac{m_{2}}{2} l_{2}{ }^{2} \dot{\theta}_{2}{ }^{2} \\
& +m_{2} l_{1} l_{2} \dot{\theta}_{1} \dot{\theta}_{2} \cos \left(\theta_{1}\right. \\
& \left.-\theta_{2}\right) \\
& +\left(m_{1}+m_{2}\right) g l_{1} \cos \theta_{1} \\
& +m_{2} g l_{2} \cos \theta_{2} .
\end{aligned}
$$

Fungsi trigonometri $\cos \theta_{1}$, dan $\cos \theta_{2}$ dapat digantikan oleh ekspresi perkiraan berikut

$$
\cos \theta_{1} \approx 1-\frac{\dot{\theta}_{1}^{2}}{2}, \quad \cos \theta_{2} \approx 1-\frac{\dot{\theta}_{2}^{2}}{2} .
$$


Diasumsikan bahwa sudut $\theta_{1}$ dan $\theta_{2}$ sangatlah kecil maka nilai $\cos \left(\theta_{1}-\theta_{2}\right)$ dapat dinyatakan sebagai berikut

$\cos \left(\theta_{1}-\theta_{2}\right) \approx \cos \theta_{1} \cos \theta_{2}+\sin \theta_{1} \sin \theta_{2} \approx 1$ maka didapatkan

$$
\begin{gathered}
L=\left(\frac{m_{1}}{2}+\frac{m_{2}}{2}\right) l_{1}{ }^{2} \dot{\theta}_{1}{ }^{2}+\frac{m_{2}}{2} l_{2}{ }^{2} \dot{\theta}_{2}{ }^{2}+m_{2} l_{1} l_{2} \dot{\theta}_{1} \dot{\theta}_{2} \\
-\left(\frac{m_{1}}{2}+\frac{m_{2}}{2}\right) g l_{1} \dot{\theta}_{1}{ }^{2}+\frac{m_{2}}{2} g l_{2} \dot{\theta}_{1}{ }^{2} .
\end{gathered}
$$

Persamaan Euler - Lagrange dinyatakan sebagai berikut

$$
\frac{d}{d t} \frac{\partial L}{\partial \dot{\theta}_{i}}-\frac{\partial L}{\partial \theta_{i}}=0, \quad i=1,2
$$

sehingga diperoleh sistem bandul ganda dengan asumsi sudut osilasi yang kecil

$$
\begin{aligned}
& \left\{\begin{array}{c}
\frac{d}{d t}\left[\left(m_{1}+m_{2}\right) l_{1}^{2} \dot{\theta}_{1}+m_{2} l_{1} l_{2} \dot{\theta}_{2}\right]+\left(m_{1}+m_{2}\right) g l_{1} \theta_{1}=0 \\
\frac{d}{d t}\left[m_{2} l_{2}^{2} \dot{\theta}_{2}+m_{2} l_{1} l_{2} \dot{\theta}_{1}\right]-m_{2} g l_{2} \theta_{2}=0
\end{array}\right. \\
& \text { atau } \\
& \left\{\begin{array}{c}
\left(m_{1}+m_{2}\right) l_{1}^{2} \ddot{\theta}_{2}+m_{2} l_{1} l_{2} \ddot{\theta}_{2}+\left(m_{1}+m_{2}\right) g l_{1} \theta_{1}=0 \\
m_{2} l_{2}^{2} \ddot{\theta}_{2}+m_{2} l_{1} l_{2} \ddot{\theta}_{1}-m_{2} g l_{2} \theta_{2}=0
\end{array}\right.
\end{aligned}
$$

\section{Nilai Eigen dan Vektor Eigen}

Misalkan matriks $A$ adalah matriks $n \times n$, maka vektor tak nol x di dalam $\mathcal{R}^{n}$ dinamakan vektor eigen (eigenvector) dari $A$ adalah kelipatan skalar dari x; yakni,

$$
A \mathrm{x}=\lambda \mathrm{x}
$$

untuk suatu skalar $\lambda$. Skalar $\lambda$ dinamakan nilai eigen dari $A$ dan x dikatakan vektor eigen yang bersesuaian dengan $\lambda[4]$.

\section{Solusi dan Potret Fase dengan Nilai Eigen Kompleks}

Persamaan diferensial $\dot{\mathrm{x}}=a \mathrm{x}$ memiliki solusi $\mathrm{x}(t)=\mathrm{x}_{0}(t) e^{a t}$ dengan $\mathrm{x}(t)$ merupakan variabel yang bergantung pada waktu $t, a$ merupakan parameter dan kondisi awal $\mathrm{x}_{0}$ yang berbeda [5].

Selanjutnya untuk solusi dari nilai eigen kompleks, diperlukan untuk memahami eksponensial dengan eksponen kompleks. Dengan membandingkan ekspansi deret kuasa, dapat dilihat bahwa

$$
\begin{gathered}
e^{i \beta t}=\cos (\beta t)+i \sin (\beta t), \\
e^{(\alpha+i \beta) t}=e^{\alpha t} e^{i \beta t}=e^{\alpha t}(\cos (\beta t)+i \sin (\beta t))
\end{gathered}
$$

Demikian, jika $\lambda=\alpha+i \beta$ adalah nilai eigen kompleks dengan vektor kompleks $\mathrm{v}=$ $\mathrm{u}+i \mathrm{w}$ (dengan $\alpha$ dan $\beta$ adalah bilangan real serta $\mathrm{u}$ dan $\mathrm{w}$ adalah vektor real), maka

$$
\begin{aligned}
e^{(\alpha+i \beta) t}(\mathrm{u}+i \mathrm{w}) & =e^{\alpha t}(\cos (\beta t)+i \sin (\beta t))(\mathrm{u} \\
& +i \mathrm{w})
\end{aligned}
$$

Berikutnya adalah menggambar potret fase untuk sepasang nilai eigen kompleks.
Diasumsikan sebuah nilai eigen adalah $\lambda=\alpha \pm$ $i \beta$ dengan $\beta \neq 0$ [5]

1. Jika $\alpha=0$, maka titik tetap adalah elliptic center, dengan solusi periodik. Arah gerakan yaitu searah jarum jam atau berlawanan dengan jarum jam.

2. Jika $\alpha<0$, maka titik tetap adalah stable focus. Arah gerakan yaitu searah jarum jam atau berlawanan dengan jarum jam.

3. Jika $\alpha>0$, maka solusi spiral keluar dan titik tetap adalah unstable focus, dengan arah gerak spiral yaitu searah jarum jam atau berlawanan dengan jarum jam.

4. Dalam tiga kasus di atas, arah solusi menuju ke sekitar titik tetap dapat ditentukan dengan mengecek apakah $\dot{x}_{1}$ adalah positif atau negatif ketika $x_{1}=0$. Jika $\dot{x}_{1}$ positif maka solusi searah dengan jarum jam dan jika $\dot{x}_{1}$ negatif maka solusi berlawanan dengan jarum jam.

\section{PEMBAHASAN}

\section{Analisis Perilaku Sistem Bandul Ganda Sederhana}

Riset pendahuluan bandul ganda sederhana [1] telah dilakukan penondimensionalan terhadap sistem bandul ganda sederhana, dimisalkan

$a=\left(m_{1}+m_{2}\right) l_{1} g$,

$b=\left(m_{1}+m_{2}\right) l_{1}{ }^{2}$,

$h=m_{2} l_{2} g$,

$j=m_{2} l_{1} l_{2}$,

$k=m_{2} l_{2}$

dengan $a, b, j, h$, dan $k>0$. Oleh karena itu sistem persamaan bandul ganda dapat ditulis sebagai berikut

$$
\left\{\begin{array}{l}
b \ddot{\theta}_{1}+j \ddot{\theta}_{2}=-a \theta_{1} \\
j \ddot{\theta}_{1}+k \ddot{\theta}_{2}=-h \theta_{2}
\end{array} .\right.
$$

Misalkan $\quad x_{1}=\theta_{1}, \quad x_{2}=\dot{\theta}_{1}, \quad \dot{x}_{2}=\ddot{\theta}_{1}, \quad x_{3}=$ $\theta_{2}, x_{4}=\dot{\theta}_{4}$ dan $\dot{x}_{4}=\ddot{\theta}_{2}$ maka diperoleh

$\left\{\begin{array}{l}\dot{x}_{1}=\dot{\theta}_{1} \\ \dot{x}_{2}=\ddot{\theta}_{1} \\ \dot{x}_{3}=\dot{\theta}_{2} \\ \dot{x}_{4}=\ddot{\theta}_{2}\end{array}\right.$

atau dapat ditulis

$\left\{\begin{array}{c}\dot{x}_{1}=x_{2} \\ \dot{x}_{2}=\frac{-a k}{-j^{2}+b k} x_{1}+\frac{j h}{-j^{2}+b k} x_{3} \\ \dot{x}_{3}=x_{4} \\ \dot{x}_{4}=\frac{-a j}{j^{2}-b k} x_{1}+\frac{b h}{j^{2}-b k} x_{3}\end{array}\right.$

Sistem (10) menunjukkan bahwa laju kecepatan benda pertama dipengaruhi oleh besar $\frac{-a k}{-j^{2}+b k}$ dari perpindahan sudut bandul pertama ditambah besar $\frac{j h}{-j^{2}+b k}$ dari 
perpindahan sudut benda kedua. Laju kecepatan bandul kedua dipengaruhi oleh besar $\frac{-a j}{j^{2}-b k}$ dari perpindahan sudut bandul pertama dan besar $\frac{b h}{j^{2}-b k}$ dari perpindahan sudut bandul kedua.

\section{Analisis Titik Tetap}

Analisis titik tetap dikerjakan dengan mengasumsikan bahwa

$$
\begin{aligned}
& \dot{x}_{1}=\frac{d x_{1}}{d t}=0, \dot{x}_{2}=\frac{d x_{2}}{d t}=0, \\
& \dot{x}_{3}=\frac{d x_{3}}{d t}=0, \dot{x}_{4}=\frac{d x_{4}}{d t}=0 .
\end{aligned}
$$

Maka, didapatkan sistem linier untuk model bandul ganda sederhana sebagai berikut:

$$
\begin{aligned}
& 0=x_{2} \\
& 0=\frac{-a k}{-j^{2}+b k} x_{1}+\frac{j h}{-j^{2}+b k} x_{3} \\
& 0=x_{2} \\
& 0=\frac{-a j}{j^{2}-b k} x_{1}+\frac{b h}{j^{2}-b k} x_{3}
\end{aligned}
$$

Oleh karena itu, sistem (11) mempunyai pemecahan trivial sehingga didapatkan titik tetap yaitu

$$
F=\left(x_{1}, x_{2}, x_{3}, x_{4}\right)=(0,0,0,0)
$$

Sistem bandul ganda sederhana hanya memiliki satu titik tetap yaitu $F=$ $\left(x_{1}, x_{2}, x_{3}, x_{4}\right)=(0,0,0,0)$ yang berarti bahwa posisi seimbang pada bandul ganda sederhana ketika sudut perpindahan benda pertama suatu waktu, laju kecepatan benda pertama terhadap waktu, sudut perpindahan benda kedua suatu waktu dan laju kecepatan benda kedua terhadap waktu sama dengan nol $\left(\theta_{1}(t)=\right.$ $\left.\ddot{\theta}_{1}(t)=\theta_{2}(t)=\ddot{\theta}_{2}(t)=0\right)$. Posisi seimbang merupakan posisi dimana energi potensial mencapai harga minimum dan merupakan posisi untuk keseimbangan stabil.

\section{Contoh Kasus}

Contoh analisis perilaku sistem bandul ganda sederhana diberikan untuk memahami lebih dalam mengenai perilaku pada sistem bandul ganda sederhana. Contoh kasus dengan parameter $m_{1}=937,5$ slug, $m_{2}=312,5$ slug, $l_{1}=16 \mathrm{kaki}, l_{2}=16 \mathrm{kaki}$, dan $g=32 \mathrm{kaki} / \mathrm{s}^{2}$ dengan kondisi awal yang berbeda $x_{1}(0)=$ $-0,5 \mathrm{rad}, x_{2}(0)=-1 \mathrm{rad} / \mathrm{s}, x_{3}(0)=1 \mathrm{rad}$, dan $x_{4}(0)=2 \mathrm{rad} / \mathrm{s}$.

Pandang sistem linier (10) menjadi sebuah matriks

$$
\dot{\mathrm{x}}=A \mathrm{x}
$$

dengan

$$
\dot{\mathrm{x}}=\left[\begin{array}{c}
\dot{\mathrm{x}}_{1} \\
\dot{\mathrm{x}}_{2} \\
\dot{\mathrm{x}}_{3} \\
\dot{\mathrm{x}}_{4}
\end{array}\right],
$$

$$
\begin{aligned}
A & =\left[\begin{array}{cccc}
0 & 1 & 0 & 0 \\
-a k & 0 & j h & 0 \\
\hdashline-j^{2}+b k & & -j^{2}+b k & \\
0 & 0 & 0 & 1 \\
\frac{-a j}{j^{2}-b k} & 0 & \frac{b h}{j^{2}-b k} & 0
\end{array}\right], \\
\mathrm{x} & =\left[\begin{array}{l}
\mathrm{x}_{1} \\
\mathrm{x}_{2} \\
\mathrm{x}_{3} \\
\mathrm{x}_{4}
\end{array}\right] .
\end{aligned}
$$

Substitusi parameter ke persamaan (7) kemudian ke persamaan (10) sehingga didapatkan

$$
\left[\begin{array}{l}
\dot{\mathrm{x}}_{1} \\
\dot{\mathrm{x}}_{2} \\
\dot{\mathrm{x}}_{3} \\
\dot{\mathrm{x}}_{4}
\end{array}\right]=\left[\begin{array}{cccc}
0 & 1 & 0 & 0 \\
\frac{-512}{192} & 0 & \frac{128}{192} & 0 \\
0 & 0 & 0 & 1 \\
\frac{512}{192} & 0 & \frac{-512}{192} & 0
\end{array}\right]\left[\begin{array}{l}
\mathrm{x}_{1} \\
\mathrm{x}_{2} \\
\mathrm{x}_{3} \\
\mathrm{x}_{4}
\end{array}\right],
$$

kondisi awal yang diberikan adalah

$$
\left[\begin{array}{c}
\mathrm{x}_{1}(0)=-0,5 \\
\mathrm{x}_{2}(0)=-1 \\
\mathrm{x}_{3}(0)=1 \\
\mathrm{x}_{4}(0)=2
\end{array}\right]
$$

Sistem (12) memiliki solusi sebagai berikut

atau dapat ditulis

$$
\mathbf{x}=\mathbf{x}_{0} e^{A t}
$$

$\left[\begin{array}{l}x_{1}(t) \\ x_{2}(t) \\ x_{3}(t) \\ x_{4}(t)\end{array}\right]=\left[\begin{array}{llll}e^{A_{1,1} t} & e^{A_{1,2} t} & e^{A_{1,3} t} & e^{A_{1,4} t} \\ e^{A_{2,1} t} & e^{A_{2,2} t} & e^{A_{2,3} t} & e^{A_{2,4} t} \\ e^{A_{3,1} t} & e^{A_{3,2} t} & e^{A_{3,3} t} & e^{A_{3,4} t} \\ e^{A_{4,1} t} & e^{A_{4,2} t} & e^{A_{4,3} t} & e^{A_{4,4} t}\end{array}\right]\left[\begin{array}{c}-0,5 \\ -1 \\ 1 \\ 2\end{array}\right]$.

Menentukan perilaku dari $e^{A t}$ saat $t \rightarrow \infty$ dengan memenuhi

$$
e^{A t}=\mathbf{v} e^{\lambda t} \mathbf{v}^{-\mathbf{1}}
$$

dimana $\lambda$ merupakan nilai eigen dan $\mathbf{v}$ merupakan vektor eigen yang bersesuaian dengan $\lambda$ serta $\mathbf{v}^{\mathbf{- 1}}$ merupakan invers dari vektor eigen. Selanjutnya, menentukan nilai eigen dari persamaan karakteristik yang memenuhi

$$
\operatorname{det}(A-\lambda \mathrm{I})=0
$$

Persamaan karakteristik $A$ adalah

$$
\lambda^{4}+1\left(\frac{128}{192}\right) 1\left(\frac{512}{192}\right)-1\left(\frac{-512}{192}\right) 1\left(\frac{-512}{192}\right)=0 .
$$

Sehingga dengan menggunakan bantuan Maple 12 nilai-nilai eigen dari matriks $A$ adalah

$$
\begin{array}{cc}
\lambda_{1}=\frac{2}{3} \sqrt{3} i, & \lambda_{2}=-\frac{2}{3} \sqrt{3} i, \\
\lambda_{3}=2 i, & \lambda_{4}=-2 i .
\end{array}
$$

Vektor eigen yang bersesuaian dengan nilai eigen adalah 


$$
\mathbf{v}=\left[\begin{array}{cccc}
-\frac{1}{4} \sqrt{3} i & \frac{1}{4} \sqrt{3} i & \frac{1}{4} i & -\frac{1}{4} i \\
\frac{1}{2} & \frac{1}{2} & -\frac{1}{2} & -\frac{1}{2} \\
-\frac{1}{2} \sqrt{3} i & \frac{1}{2} \sqrt{3} i & -\frac{1}{2} i & \frac{1}{2} i \\
1 & 1 & 1 & 1
\end{array}\right] .
$$

Selanjutnya menentukan masing-masing solusi umum dari $\mathrm{x}_{1}(t), \mathrm{x}_{2}(t), \mathrm{x}_{3}(t)$ dan $\mathrm{x}_{4}(t)$.

$$
\begin{aligned}
\mathrm{x}_{1}(t)= & C_{1}\left(-\frac{1}{4} \sin (2 t)\right)+C_{2}\left(\frac{1}{4} \cos (-2 t)\right) \\
& +C_{3}\left(\frac{1}{4} \sqrt{3} \sin \left(\frac{2}{3} \sqrt{3} t\right)\right) \\
& +C_{4}\left(\frac{1}{4} \sqrt{3} \cos \left(-\frac{2}{3} \sqrt{3} t\right)\right) \\
\mathrm{x}_{2}(t)= & C_{1}\left(-\frac{1}{2} \cos (2 t)\right)+C_{2}\left(\frac{1}{2} \sin (-2 t)\right)+ \\
& C_{3}\left(\frac{1}{2} \cos \left(\frac{2}{3} \sqrt{3} t\right)\right) \\
& +C_{4}\left(\frac{1}{2} \sin \left(-\frac{2}{3} \sqrt{3} t\right)\right) \\
\mathrm{x}_{3}(t)= & C_{1}\left(\frac{1}{2} \sin (2 t)\right)+C_{2}\left(-\frac{1}{2} \cos (-2 t)\right) \\
& +C_{3}\left(\frac{1}{2} \sqrt{3} \sin \left(\frac{2}{3} \sqrt{3} t\right)\right) \\
& +C_{4}\left(-\frac{1}{2} \sqrt{3} \cos \left(-\frac{2}{3} \sqrt{3} t\right)\right) \\
\mathrm{x}_{4}(t)= & C_{1} \cos (2 t)+C_{2} \sin (-2 t) \\
& +C_{3} \cos \left(\frac{2}{3} \sqrt{3} t\right) \\
& +C_{4} \sin \left(-\frac{2}{3} \sqrt{3} t\right)
\end{aligned}
$$

Solusi khusus dengan $C_{1}=1, C_{2}=1, C_{3}=1$, dan $C_{4}=-\frac{3}{\sqrt{3}}$ adalah

$$
\begin{aligned}
\mathrm{x}_{1}(t)= & -\frac{1}{4} \sin (2 t)+\frac{1}{4} \cos (-2 t) \\
& +\frac{1}{4} \sqrt{3} \sin \left(\frac{2}{3} \sqrt{3} t\right)-\frac{3}{4} \cos \left(-\frac{2}{3} \sqrt{3} t\right) \\
\mathrm{x}_{2}(t)= & -\frac{1}{2} \cos (2 t)+\frac{1}{2} \sin (-2 t) \\
& +\frac{1}{2} \cos \left(\frac{2}{3} \sqrt{3} t\right)-\frac{3}{2 \sqrt{3}} \sin \left(-\frac{2}{3} \sqrt{3} t\right) \\
\mathrm{x}_{3}(t)= & \frac{1}{2} \sin (2 t)-\frac{1}{2} \cos (-2 t) \\
& +\frac{1}{2} \sqrt{3} \sin \left(\frac{2}{3} \sqrt{3} t\right)+\frac{3}{2} \cos \left(-\frac{2}{3} \sqrt{3} t\right) \\
\mathrm{x}_{4}(t)= & \cos (2 t)+\sin (-2 t) \\
& +\cos \left(\frac{2}{3} \sqrt{3} t\right)-\frac{3}{\sqrt{3}} \sin \left(-\frac{2}{3} \sqrt{3} t\right)
\end{aligned}
$$

Berikut adalah grafik perilaku dari sistem bandul ganda dengan $t=0 \ldots 50$ detik.

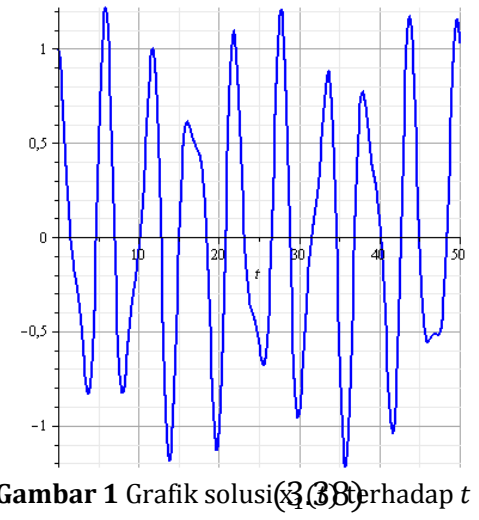

Gambar 1 merupakan grafik perubahan sudut perpindahan benda pertama terhadap waktu dengan rentang waktu 50 detik. Benda pertama mulai berayun pada sudut $-0,5 \mathrm{rad}$

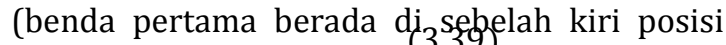
setimbang) dan bergerak mendekati posisi seimbang $(0,0)$ akan tetapi setelah benda pertama berada di posisi seimbang perlahan benda pertama menjauhi posisi seimbang, hal tersebut terjadi secara periodik. Pada gambar tersebut menunjukkan bahwa pergerakan benda pertama berubah §ecara periodik baik besar maupun arahnya di sekitar titik keseimbangan dengan periode 4,9 detik, simpangan maksimum yaitu 1,21 rad pada saat benda pertama berayun selama 5,49 detik dan selama rentang waktu 50 detik benda pertama tetap berosilasi di sekitar posisi seimbang.

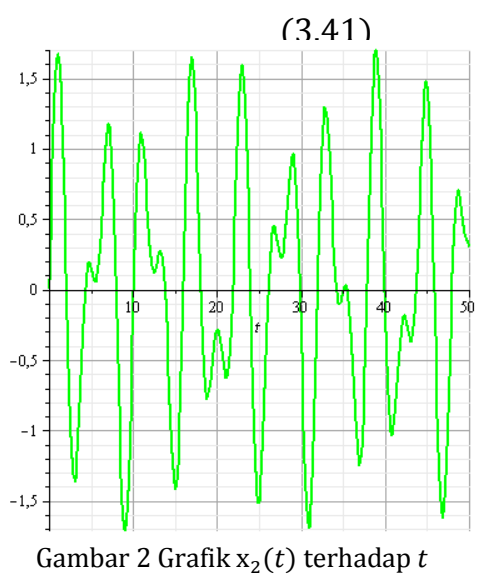

(3.50)

Gambar 2 merupakan grafik laju kecepatan benda pertama terhadap waktu selama rentang waktu 50 detik. Pada(3.gambar tersebut menunjukkan bahwa laju kecepatan awal benda pertama terhadap waktu sebesar $1 \mathrm{rad} / \mathrm{s}^{2}$ (benda pertama berada di sebelah kanan posisi seimbang) dan kecepatannya berubah secara quasiperiodic baik besar maupun arahnya. Benda kedua memiliki kecepatan maksimal saat 8,9 detik. 


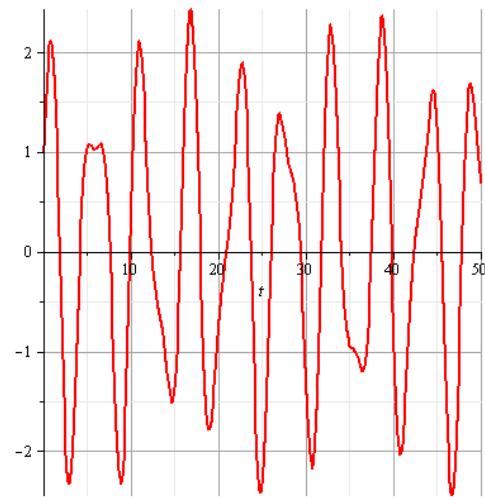

Gambar 3 Grafik $_{3}(t)$ terhadap $t$

Gambar 3 merupakan grafik perubahan sudut perpindahan benda kedua terhadap waktu selama kurung waktu 50 detik. Pada gambar tersebut menunjukkan bahwa pergerakan benda kedua berubah secara periodik baik besar maupun arahnya di sekitar titik keseimbangan dengan periode 4,91 detik dan simpangan maksimum yaitu 16,76 rad saat $t=2,43$ detik.

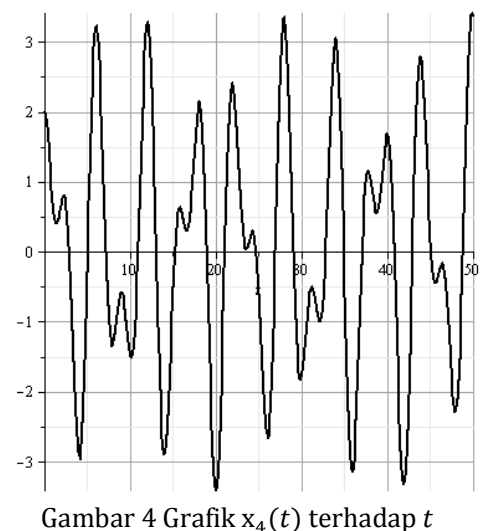

Gambar 4 merupakan grafik laju kecepatan bandul kedua terhadap waktu dengan $t=$ $0 \ldots 50$ detik. Pada gambar tersebut menunjukkan bahwa laju kecepatan awal sebesar $-0.5 \mathrm{rad}$, bandul kedua terhadap waktu berubah secara quasiperiodic baik besar maupun arahnya. Pada saat $t=19,94$ detik bandul kedua memiliki laju kecepatan maksimal.

\section{Deskripsi Pengaruh Parameter terhadap Kestabilan Perilaku sistem Bandul Ganda Sederhana}

Parameter Massa Benda Pertama lebih besar daripada Massa Benda Kedua $\left(m_{1}>\right.$ $m_{2}$ )

Simulasi pertama dengan massa benda pertama sebesar 412.5 slug dan massa benda kedua sama dengan 312.5 slug. Bandul pertama mulai bergerak saat sudut perpindahan sebesar $-0,5$ rad (benda pertama berada di sebelah kiri posisi seimbang sebesar $-0,5 \mathrm{rad}$ ) dan laju kecepatannya $1 \mathrm{rad} / \mathrm{s}^{2}$ (benda pertama berada di sebelah kanan posisi seimbang dengan kecepatan $1 \mathrm{rad} / \mathrm{s}^{2}$ ).

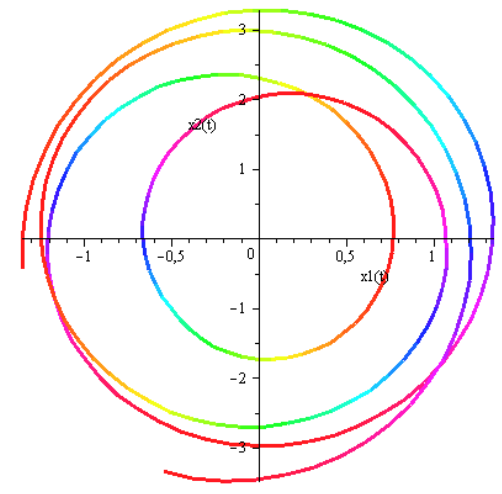

Gambar 5 Trayektori dengan $m_{1}>m_{2}$

Gambar 5 memperlihatkan bahwa trayektori bergerak searah jarum jam untuk mendekati titik tetap sampai akhirnya mulai menjauhi titik tetap saat $t>0$ detik artinya kestabilan dari sistem adalah tidak stabil. Periode dari sistem bandul ganda sederhana berangsur-angsur membesar sampai $t \rightarrow \infty$.

Parameter Massa Benda Pertama sama dengan Massa Benda Kedua $\left(m_{1}=m_{2}\right)$

Simulasi kedua dengan massa benda pertama sebesar 312,5 slug dan massa benda kedua sama dengan 312,5 slug. Benda pertama mulai bergerak saat sudut perpindahan sebesar $-0,5 \mathrm{rad}$ dan laju kecepatannya $1 \mathrm{rad} / \mathrm{s}^{2}$.

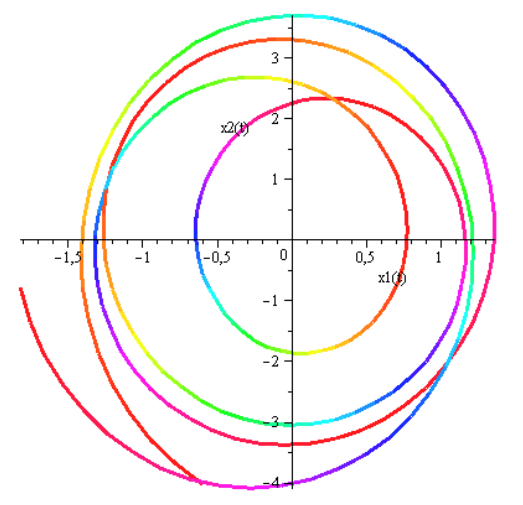

Gambar 6 Trayektori dengan $m_{1}=m_{2}$

Gambar 6 memperlihatkan bahwa trayektori bergerak melawan arah jarum jam untuk mendekati titik tetap sampai akhirnya mulai menjauhi titik tetap saat $t>0$ detik artinya kestabilan dari sistem adalah tidak stabil. Periode dari sistem bandul ganda sederhana berangsur-angsur membesar sampai $t \rightarrow \infty$. 
Parameter Massa Benda Pertama lebih besar daripada Massa Benda Kedua $m_{1}<$ $\boldsymbol{m}_{2}$

Simulasi pertama dengan massa benda pertama sebesar 212.5 slug dan massa benda kedua sama dengan 312.5 slug. Bandul pertama mulai bergerak saat sudut perpindahan sebesar $-0,5 \mathrm{rad}$ dan laju kecepatannya $1 \mathrm{rad} / \mathrm{s}^{2}$.

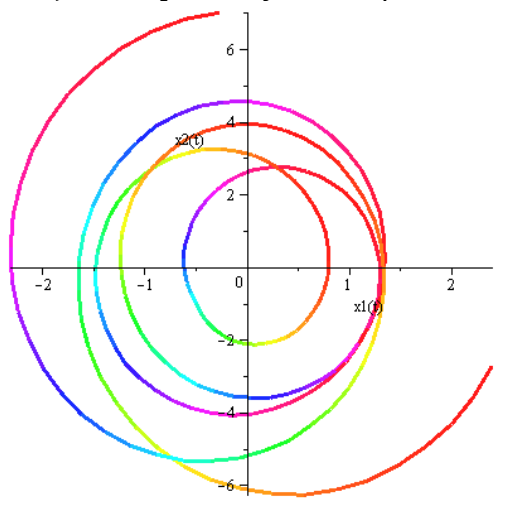

Gambar 7 Trayektori dengan $m_{1}<m_{2}$

Gambar 7 memperlihatkan bahwa trayektori bergerak melawan arah jarum jam untuk mendekati titik tetap sampai akhirnya mulai menjauhi titik tetap saat $t>0$ detik artinya kestabilan dari sistem adalah tidak stabil. Periode dari sistem bandul ganda sederhana berangsur-angsur membesar sampai $t \rightarrow \infty$. Oleh karena itu, perubahan parameter tidak mempengaruhi kestabilan sistem melainkan hanya arah trayektorinya saja.

\section{PENUTUP}

\section{Kesimpulan}

Berdasarkan pembahasan di atas maka dapat diperoleh kesimpulan sebagai berikut:

1. Model bandul ganda sederhana tersebut memiliki titik tetap saat $F=$ $\left(x_{1}, x_{2}, x_{3}, x_{4}\right)=(0,0,0,0)$ artinya sistem memiliki posisi seimbang ketika sudut perpidahan benda pertama dan kedua suatu waktu serta laju kecepatan benda pertama dan kedua terhadap waktu sama dengan nol. Nilai eigen dari sistem bandul ganda dengan parameter tertentu adalah imajiner murni berarti kestabilan dari sistem bandul ganda yaitu tak stabil dan tipe kestabilan sistem bandul ganda sederhana adalah elliptic center. Grafik perpindahan bandul pertama dan kedua terhadap waktu adalah periodik dan grafik laju kecepatan bandul pertama dan kedua adalah quasiperiodic. Hal tersebut menunjukkan bahwa sistem bandul ganda bergerak bolak-balik melalui lintasan yang sama. Perubahan besar parameter benda pertama tidak mempengaruhi kestabilan sistem.

\section{Saran}

Penelitian ini difokuskan pada masalah analisis perilaku sistem bandul ganda sederhana. Pada penelitian selanjutnya penulis menyarankan untuk analisis bifurkasi pada sistem bandul ganda sederhana karena telah diketahui bahwa sistem bandul ganda sederhana memiliki nilai eigen murni yang merupakan syarat cukup untuk analisis bifurkasi.

\section{DAFTAR PUSTAKA}

[1] Amanto and La Zakaria, "Solusi Eksak dan Kestabilan Sistem Bandul Ganda sederhana," Jurnal Sains MIPA, pp. 23-32, 2008.

[2] Asep K. Supriatna, "Matematika dan Contoh Penerapan Matematika dalam Disiplin Ilmu Lain," Matematika Integratif, pp. 1-7, 2002.

[3] Robert Resnick and David Halliday, Physics, 3'th Edition. Jakarta: Erlangga, 1978.

[4] Howard Anton, Elementary Linier Algebra, Jilid I. Bandung: Erlangga, 1997.

[5] R C Robinson, An Introduction to Dynamical System Continous and Discrete. Western: American Mathematical Society , 2012. 